\title{
Evaluation of Plateletcrit and Neutrophil/Lymphocyte, Monocyte/Lymphocyte and Platelet/Lymphocyte Ratios in Endometrial Polyp
}

\author{
Endometriyal Polipte Plateletkrit, Nötrofil/Lenfosit, Monosit/Lenfosit ve Platelet/ \\ Lenfosit Oranlarının Değerlendirilmesi
}

\author{
(D) Anıl Turhan Çakır', (1) İsa Şükrü Öz² \\ 1Zonguldak Maternity and Child Health Hospital, Clinic of Gynecologic Oncology, Zonguldak, Turkey \\ 2Zonguldak Maternity and Child Health Hospital, Clinic of Gynecology and Obstetrics, Zonguldak, Turkey
}

\begin{abstract}
Introduction: To evaluate the association between endometrial polyp (EP) and inflammatory markers such as neutrophil/lymphocyte ratio (NLR), platelet/lymphocyte ratio (PLR), monocyte/lymphocyte ratio (MLR) and plateletcrit (PCT).

Methods: In this retrospective and comparative case series, a total of 137 patients who had undergone endometrial biopsy due to various causes were included. Forty-eight of these patients were diagnosed with EP and classified as the patient group. Eighty-nine patients were diagnosed with proliferative/ secretory endometrium and classified as the control group. The groups' PCT, NLR, PLR and MLR values were compared as statistically.
\end{abstract}

Results: There was no significant difference between the EP and control groups in terms of the NLR, PLR and MLR and the PCT value.

Conclusion: This is the first study in the literature evaluating the relationship between NLR, PLR and MLR and PCT value and EP. Further large-scale studies are essential to determine the exact role of NLR, PLR and MLR and PCT value on EPS.

Keywords: Endometrial diseases, polyps, blood cell count

\section{öZ}

Amaç: Endometriyal polip (EP) ile nötrofil/lenfosit oranı (NLO), platelet/lenfosit oranı (PLO), monosit/lenfosit oranı (MLO) ve plateletkrit (PCT) gibi enflamasyon belirteçleri arasındaki ilişkiyi değerlendirmektir.

Yöntemler: Bu retrospektif karșılaştırmalı olgu serisine, çeșitli nedenlerle endometriyal biyopsi yapılan toplam 137 hasta dahil edildi. Bu hastaların 48'i EP tanısını alarak hasta grubu olarak sınıflanırken 89 hasta proliferatif/sekretuvar endometrium tanısı alarak kontol grubu olarak sınıflandı. Grupların NLO, PLO, MLO ve PCT değerleri istatistiksel olarak karşılaștırıldı.

Bulgular: EP ve kontrol grupları arasında NLO, PLO, MLO ve PCT değerleri açısından anlamlı fark saptanmadı.

Sonuç: Bu çalıșma; NLO, PLO, MLO ve PCT değerleri ile EP arasındaki ilișkiyi irdeleyen ilk çalıșmadır. NLO, PLO, MLO ve PCT değerlerinin EP'deki rolünü belirlemek için geniş katılımlı çalıșmalara ihtiyaç vardır.

Anahtar Kelimeler: Endometriyal hastalıklar, polipler, kan hücresi sayımı

\section{Introduction}

Endometrial polyp (EP) is a frequent disease of the endometrium, characterised by a localised hyperplastic over growth of endometrial glands and stroma around a vascular core and the presence of inflammatory cells in the stroma (1). Although the etiopathogenesis has not been fully elucidated, oestrogen and progesterone, apoptosis, growth factors, metabolism and ageing, selective oestrogen receptor modulators, hormone replacement therapy, Ki-67 and also endometrial inflammation may play a role in its etiopathogenesis $(2,3)$.
Although many EPs are asymptomatic, abnormal uterine bleeding is the most common symptom of EP. Even though transvaginal ultrasonography (TVUSG) provides reliable data for the diagnosis of EP, hysteroscopy is the gold standard diagnostic procedure that is also simultaneously used for treatment.

Neutrophil/lymphocyte ratio (NLR), platelet/lymphocyte ratio (PLR), monocyte/lymphocyte ratio (MLR) and plateletcrit (PCT) in peripheral blood are values that are simple to calculate, have a very low cost and can reveal the systemic inflammation. 
There is no study in the literature that evaluates the relationship between NLR, PLR and MLR and PCT value and EP. In this study, we aimed to investigate the association between symptomatic EPs without ultrasonographic EP-compatible views and inflammation markers (NLR, PLR, MLR and P(T).

\section{Methods}

In this retrospective and comparative case series, a total of 137 patients who had undergone endometrial biopsy due to various causes between June 2017 and March 2019 at Zonguldak Maternity and Child Health Hospital were evaluated. This study was approved by the Clinical Research Ethics Committee of Zonguldak Bülent Ecevit University, Turkey (protocol no: 2019-75-08/05, date: 08.05.2019). Patients' consent was not obtained because the study was retrospective. Forty-eight of these patients were diagnosed with EP and classified as the patient group. EPcompatible views such as dilated glands filled with proteinaceous fluid or a hyperechogenic lesion with regular contours were not detected on ultrasonography prior to the endometrial biopsy. Eighty-nine patients were diagnosed with proliferative/secretory endometrium and classified as the control group. Patient with a history of malignancy, pelvic inflammatory disease, severe liver, kidney and cardiac disease, chronic inflammatory disease and those who received hormone replacement therapy were excluded. Patients' demographic characteristics, pathology results and laboratory values were extracted from the automation system of the hospital. PCT, neutrophil count, lymphocyte count, monocyte count, platelet count values were obtained from complete blood cell count parameters within a month before the endometrial biopsy. PLR value was calculated by dividing the platelet count by the number of lymphocytes. NLR value was calculated by dividing the neutrophil count by the number of lymphocytes and MLR value was calculated by dividing the monocyte count by the number of lymphocytes. The groups' PCT, NLR, PLR and MLR values were compared statistically.

\section{Statistical Analysis}

IBM SPSS 22.0 (IBM SPSS Statistics, IL, USA) was used for all the statistical analyses. Data distribution was determined using the KolmogorovSmirnov test. Continuous variables were expressed as means \pm standard deviations and categorical variables as frequencies and percentages. Continuous variables were compared by an independent sample t-test or Mann-Whitney $U$ test. $p<0.05$ was considered significant for all the tests.

\section{Results}

The mean age of the 48 patients diagnosed as EP was $45.5 \pm 8.9$ and the mean age of the 89 patients diagnosed as proliferative/secretory endometrium was $43.4 \pm 6.3$. There was no significant difference in the terms of age between the two groups $(p=0.158)$. Endometrial biopsy was performed in 39 patients with abnormal uterine bleeding, 3 patients with postmenopausal increased endometrial thickness, 4 patients with endometrial irregularity and 2 patients with postmenopausal bleeding in the EP group. In the control group, all the patients had undergone endometrial biopsy due to abnormal uterine bleeding. The blood cell count data of the EP and control groups are shown in Table 1. Neutrophil, lymphocyte, monocyte and platelet count of the groups were not significantly different. NLR, PLR and MLR of the EP group was $2.32 \pm 1.46,137.14 \pm 66.40$ and $0.20 \pm 0.13$ and in the control group was $2.72 \pm 3.58,135.05 \pm 62.44$ and $0.20 \pm 0.26$, respectively. The PCT value in the EP group was $0.22 \pm 0.05$ and in the control group was $0.22 \pm 0.05$. There was no significant difference between the two groups in terms of the NLR, PLR and MLR and PCT value $(p=0.458, p=0.856, p=0.995$, $\mathrm{p}=0.963)$ (Table 1).

\section{Discussion}

EP is one of the causes of abnormal uterine bleeding. They are usually benign, but can have premalignant or malignant tissue variations. Polyps are rare before 30 years and peak in the postmenopausal period (4). Increased fibrotic tissue compared to the normal endometrium, thickwalled blood vessels and inflammatory cells like polymorphonuclear leucocytes, lymphocytes and plasma cells in the stroma are pathologic features of EP (1).

The etiopathogenesis of EP remains unclear. Some studies reported that cytokines like cyclooxygenase, interferon-gamma, aromatase and matrix metalloproteinases can cause EP by causing angiogenesis and cell proliferation $(5,6)$. Some investigators showed that EP is formed as a result of an imbalance in the expression of oestrogen and progesterone receptors $(7,8)$ and deficient apoptosis through the loss of the regulation of $\mathrm{BCl}-2$ and $\mathrm{Ki}-67(9,10)$. The endometrial inflammatory state can stop the apoptosis in the endometrium and may cause EPs. Endometritis, endometriosis, adenomyosis are examples of pro-inflammatory states (2).

NLR, PLR, MLR and PCT are systemic inflammatory response markers and are associated with several diseases such as peripheral vascular

Table 1. Neutrophil, lymphocyte, monocyte, platelet and PCT count, NLR, PLR and MLR values in the endometrial polyp and control groups

\begin{tabular}{|l|l|l|l|}
\hline & Endometrial polyp & Control group & p \\
\hline Neutrophil $(\mu \mathrm{L})$ & $0.36 \pm 0.14$ & $0.35 \pm 0.15$ & 0.294 \\
\hline Lymphocyte $(\mu \mathrm{L})$ & $2.13 \pm 0.91$ & $2.06 \pm 0.70$ & 0.635 \\
\hline Monocyte $(\mu \mathrm{L})$ & $4.11 \pm 2.07$ & $4.72 \pm 1.73$ & 0.805 \\
\hline Platelet $(\mathrm{K} / \mu \mathrm{L})$ & $250.21 \pm 66.10$ & $254.20 \pm 62.10$ & 0.728 \\
\hline PCT $(\%)$ & $0.22 \pm 0.05$ & $0.22 \pm 0.05$ & 0.963 \\
\hline NLR & $2.32 \pm 1.46$ & $2.72 \pm 3.58$ & 0.458 \\
\hline PLR & $137.14 \pm 66.40$ & $135.05 \pm 62.44$ & 0.856 \\
\hline MLR & $0.20 \pm 0.13$ & $0.20 \pm 0.26$ & 0.995 \\
\hline PC: & & Ple & \\
\hline
\end{tabular}

PCT: Plateletcrit, NLR: neutrophil/lymphocyte ratio, PLR: platelet/lymphocyte ratio, MLR: monocyte/lymphocyte ratio 
disease, coronary artery disease, malignancies, rheumatoid arthritis and ulcerative colitis (11-15).

Recurrent pregnancy loss is defined as 3 consecutive pregnancy losses prior to 20 weeks of gestation. The aetiology of $50 \%$ of recurrent pregnancy loss is unexplained, but inflammation and coagulation disorders play a significant role. In a study with 208 patients who had 2 or more first trimester spontaneous abortions; white blood cell, platelet, lymphocyte and neutrophil count, red cell distribution width, PCT and NLR in the recurrent pregnancy loss group were significantly higher than in the control group (16).

Nasal polyp is characterised by progressive inflammation with eosinophil, T-cell, neutrophil and plasma cell. The study by Atan et al. (17) included 105 patients diagnosed as nasal polyp. In the nasal polyp group, the mean NLR value was significantly $(p=0.001)$ higher than in the control group, while there was no significant difference in the mean PLR value.

Endometriosis is identified using ectopic endometrial tissue. It is a chronic inflammatory condition associated with findings related to inflammation like dyspareunia, dysmenorrhoea and chronic pain. Aydın (18) (187 patients), Kim et al. (19) (219 patients) and Yavuzcan et al. (20) (33 patients) reported that there is no relationship between NLR and endometrioma. On the other hand, in studies by Cho et al. (21) including 231 patients and Tokmak et al. (22) including 467 patients, NLR was found to be elevated in endometriosis cases. Furthermore, in Aydın's (18) study, PLR value in the endometrioma group was higher than in the benign cyst group, but in another study (23), there was no difference in PLR value between the two groups.

EP typically appears as cystic spaces corresponding to dilated glands filled with proteinaceous fluid or a hyperechogenic lesion with regular contours on TVUSG. EP can also be seen as a focal mass or nonspecific thickening. These findings are not specific to EP. The addition of power Doppler can enhance the diagnostic efficacy of TVUSG. Saline infusion sonography improves the diagnostic accuracy. Hysteroscopic-guided biopsy provides the highest sensitivity and specificity for the diagnosis of EP (24). Although blind endometrial biopsy has a high sensitivity and positive pressure ventilation, this technique can cause polyp fragmentation and the inaccurate diagnosis of EP (25).

EPs are generally asymptomatic. In a population-based Danish study, EP was significantly more frequent in asymptomatic women compared to women with abnormal uterine bleeding (26). Abnormal uterine bleeding is the most common symptom for the symptomatic EP (24). In a study by Kanthi et al. (27), 75.6\% of premenopausal women and $47.7 \%$ of postmenopausal women with polyps had abnormal uterine bleeding. In another study, $20 \%$ of postmenopausal women with polyp and $76.3 \%$ of premenopausal women were symptomatic with abnormal uterine bleeding (28).

In our study, we evaluated the association between the NLR, PLR and MLR and PCT value and symptomatic EP without ultrasonographic EP-compatible views. These patients were diagnosed by endometrial biopsy, but blind endometrial biopsy is inaccurate in diagnosing EP. If we could find a significant relationship between the two groups; NLR,
PLR and MLR and PCT value, which are simple to calculate and cheap, could have been effective in evaluating the diagnosis of EP before biopsy Thus, additional tests such as saline infusion sonography, Doppler ultrasonography and hysteroscopy before blind biopsy can be done.

\section{Conclusion}

There are inconsistent conclusions in the literature about NLR, PLR and MLR and PCT value in various diseases. Also, to the best of our knowledge, this is the first study in the literature appraising the association between NLR, PLR and MLR and PCT value and EPs. In our study, there was no significant difference between the symptomatic EPs without ultrasonographic EP-compatible views group and the control group in terms of the NLR, PLR and MLR and PCT value. Further largescale studies are essential to determine the exact role of NLR, PLR and MLR and PCT value on EPS.

\section{Ethics}

Ethics Committee Approval: This study was approved by the Local Ethics Committee of Zonguldak Bülent Ecevit University, Turkey (protocol no: 2019-75-08/05, date: 08.05.2019).

Informed Consent: Patients' consent was not obtained because the study was retrospective.

Peer-review: Externally peer-reviewed.

Authorship Contributions: Surgical and Medical Practices - A.T.Ç., I.Ş.Ö.; Concept - A.T.Ç., I.Ş.Ö.; Design - A.T.Ç.; Data Collection or Processing A.T.Ç.; Analysis or Interpretation - A.T.Ç., I.Ş.Ö.; Literature Search - A.T.Ç.; Writing - A.T.C..

Conflict of Interest: No conflict of interest was declared by the authors.

Financial Disclosure: The authors declared that this study received no financial support.

\section{References}

1. Buckley $\mathrm{CH}$. Normal endometrium and non-proliferative conditions of the endometrium. Fox H, Wells M, editors. Obstetrical and Gynaecological Pathology. 5th ed. London: Churchill Livingstone; 2002.p.416-7.

2. Indraccolo U, Di lorio R, Matteo M, Corona G, Greco P, Indraccolo SR. The pathogenesis of endometrial polyps: a systematic semiquantitative review. Eur J Gynaecol Oncol 2013; 34: 5-22.

3. Deligdisch L. Hormonal pathology of the endometrium. Mod Pathol 2000; 13: $285-94$

4. Dreisler E, Stampe Sorensen S, Ibsen PH, Lose G. Prevalence of endometrial polyps and abnormal uterine bleeding in a Danish population aged 20-74 years. Ultrasound Obstet Gynecol 2009; 33: 102-8.

5. Inagaki N, Ung L, Otani T, Wilkinson D, Lopata A. Uterine cavity matrix metalloproteinases and cytokines in patients with leiomyoma, adenomyosis or endometrial polyp. Eur J Obstet Gynecol and Reprod Biol 2003;111:197-203.

6. Erdemoglu E, Güney M, Karahan N, Mungan T. Expression of cyclooxygease-2, matrix metalloproteinase-2 and matrix metalloproteinase- 9 in premenopausal and postmenopausal endometrial polyps. Maturitas 2008; 59: 268-74.

7. Lopes RG, Baracat EC, de Albuquerque Neto LC, Ramos JFD, Yatabe S, Depesr $\mathrm{DB}$, et al. Analysis of estrogen- and progesterone-receptor expression in endometrial polyps. J Minim Invasive Gynecol 2007; 14: 300-3. 
8. Mittal K, Schwartz L, Goswami S, Demopoulos R. Estrogen and progesterone receptor expression in endometrial polyps. Int J Gynecol Pathol 1996; 15: 3458.

9. Taylor LJ, Jackson TL, Reid JG, Duffy SR. The differential expression of oestrogen receptors, progesterone receptors, Bcl-2 and Ki67 in endometrial polyps. BJOG 2003; 110: 794-8.

10. McGurgan P, Taylor LJ, Duffy SR, O’Donovan PJ. Are endometrial polyps from pre-menopausal women similar to post-menopausal women? An immunohistochemical comparison of endometrial polyps from pre- and post-menopausal women. Maturitas 2006; 54: 277-84.

11. Fan Y, Li X, Zhou XF, Zhang DZ, Shi XF. [Value of neutrophil lymphocyte ratio in predicting hepatitis B-related liver failure]. Zhonghua Gan Zang Bing Za Zhi 2017; 25: 726-31.

12. Sönmez O, Ertaş G, Bacaksız A, Tasal A, Erdoğan E, Asoğlu E, et al. Relation of neutrophil-to-lymphocyte ratio with the presence and complexity of coronary artery disease: an observational study. Anadolu Kardiyol Derg 2013; 13: $662-$ 7.

13. Celikbilek M, Dogan S, Ozbakır O, Zararsız G, Kücük H, Gürsoy S, et al. Neutrophil-lymphocyte ratio as a predictor of disease severity in ulcerative colitis. J Clin Lab Anal 2013; 27: 72-6.

14. Imtiaz F, Shafique K, Mirza SS, Ayoob Z, Vart P, Rao S. Neutrophil lymphocyte ratio as a measure of systemic inflammation in prevalent chronic diseases in Asian population. Int Arch Med 2012; 5: 2.

15. Tousoulis D, Antoniades C, Koumallos N, Stefanadis C. Proinflammatory cytokines in acute coronary syndromes: from bench to bedside. Cytokine Growth Factor Rev 2006; 17: 225-33.

16. Aynıoglu O, Isık H, Sahbaz A, Harma MI, Isık M, Kokturk F. Can Plateletcrit be a Marker for Recurrent Pregnancy Loss? Clin Appl Thromb Hemost 2016; 22: 447-52.

17. Atan D, Özcan KM, Köseoğlu S, İkincioğulları A, Çetin MA, Ensari S, et al. Nazal polipte yeni öngörücü parametreler: Nötrofil lenfosit oranı ve trombosit lenfosit oranı. Kulak Burun Bogaz Ihtis Derg 2015; 25: 97-101.
18. Aydın DS. Diagnostic Performance of Neutrophil/Lymphocyte Ratio and Platelet/Lymphocyte Ratio in Endometrioma. Istanbul Med J 2019; 20: 13-6.

19. Kim SK, Park JY, Jee BC, Suh CS, Kim SH. Association of the neutrophil-tolymphocyte ratio and CA 125 with the endometriosis score. Clin Exp Reprod Med 2014; 41: 151-7.

20. Yavuzcan A, Cağlar M, Ustün Y, Dilbaz S, Ozdemir I, Yıldız E, et al. Evaluation of mean platelet volume, neutrophil/lymphocyte ratio and platelet/lymphocyte ratio in advanced stage endometriosis with endometrioma. J Turk Ger Gynecol Assoc 2013; 14: 210-5.

21. Cho S, Cho H, Nam A, Kim HY, Choi YS, Park KH, et al. Neutrophil-tolymphocyte ratio as an adjunct to CA-125 for the diagnosis of endometriosis. Fertil Steril 2008; 90: 2073-9.

22. Tokmak A, Yildirim G, Öztaș E, Akar S, Erkenekli K, Gülşen P, et al. Use of neutrophil-to-lymphocyte ratio combined with ca-125 to distinguish endometriomas from other benign ovarian cysts. Reprod Sci 2016; 23: 795802.

23. Viganò P, Ottolina J, Sarais V, Rebonato G, Somigliana E, Candiani M. Coagulation status in women with endometriosis. Reprod Sci. 2017 Jul 6. doi: 10.1177/1933719117718273. [Epub ahead of print].

24. American Association of Gynecologic Laparoscopists. AAGL practice report: practice guidelines for the diagnosis and management of endometrial polyps. J Minim Invasive Gynecol 2012; 19: 3-10.

25. Hamou J. Hysteroscopy and Microcolopohysteroscopy: Text and Atlas. Norwalk: Appleton \& Lange; 1991.

26. Dreisler E, Stampe Sorensen S, Ibsen PH, Lose G. Prevalence of endometrial polyps and abnormal uterine bleeding in a Danish population aged 20-74 years. Ultrasound Obstet Gynecol 2009; 33: 102-8.

27. Kanthi JM, Remadevi C, Sumathy S, Sharma D, Sreedhar S, Jose A. Clinical Study of Endometrial Polyp and Role of Diagnostic Hysteroscopy and Blind Avulsion of Polyp. J Clin Diagn Res 2016; 10: QC01-4.

28. Preutthipan S, Herabutya Y. Hysteroscopic polypectomy in 240 premenopausal and postmenopausal women. Fertility Sterility 2005; 83: 705-9. 